\title{
7 \\ Anti-Pneumococcal Antibody and COVID 19 - A Review
}

\section{IJCRR}

Section: Healthcare

Sci. Journal Impact

Factor: $6.1(2018)$

ICV: 90.90 (2018)

(c) (7) (3)

Copyright@IJCRR

\section{Apurva Choudhary ${ }^{1}$, M. P. Brudha' ${ }^{2}$, Smiline Girija AS ${ }^{3}$}

\begin{abstract}
'Saveetha Dental College, Saveetha Institute of Medical and Technical Science, Saveetha University, Chennai, India; ${ }^{2}$ Department of Pathology, Saveetha Dental College, Saveetha Institute of Medical and Technical Science, Saveetha University, Chennai-6ooo77, India; ${ }^{3}$ Associate Professor, Department of Microbiology, Saveetha Dental College, Saveetha Institute of Medical and Technical Science, Saveetha University, Chennai-60oo77, India.
\end{abstract}

\section{ABSTRACT}

Aim: To study and learn the role of anti-pneumococcal antibody and the development of vaccines for COVID 19.

Materials and Methods: Review of Literature by collecting and retrieving information from a minimum of articles.

Discussion: The antibody-polysaccharide antigens, such as the pneumococcal vaccine. Polysaccharide pneumococcal vaccines have evolved over the past 20 years, using both unconjugated polysaccharides and polysaccharides conjugated to toxins to elicit a protective immune response in groups at risk for pneumococcal infection. Current CDC immunization guidelines for these vaccines have reduced the rates of pneumococcal infections within immunized communities. Vaccines against pneumonia, such as a pneumococcal vaccine, do protect against the COVID 19.

Conclusion: We acknowledge that the development of pneumococcal vaccine may not protect against the coronavirus. More affordable and accessible vaccines for pneumonia are needed to protect from vaccines to kill the coronavirus in one shot. As the virus is new and different as it needs its vaccine.

Key Words: Anti-pneumococcal antibody, Pneumonia, SARS, COVID-19, Vaccine, Pneumococcal infection

\section{INTRODUCTION}

Severe acute respiratory syndrome coronavirus 2 that is SARS-CoV-2 has become a pandemic and people are confronting it. It appears that the coronavirus has been in multiple countries and billions of people. There is wide variability in the anti-pneumococcal antibody response of normal subjects as shown in one study ${ }^{1}$. Anti-capsular polysaccharide antibodies are believed to represent the single most important protective mechanism against invasive disease. The basis of serum therapy was antibodies to pneumococcal polysaccharides in which passively transferred, serotype-specific anti-pneumococcal serum has reduced mortality from pneumococcal pneumonia by making it into half ${ }^{2}$. The example of antibody-polysaccharide antigens includes pneumococcal vaccine.

Streptococcus pneumoniae has capsular polysaccharide and shows a diverse group of polymers. A previous study demonstrated the virulence of bacterium and its essential role with 90 serologically distinct capsules ${ }^{3}$. Vaccination of infants and young children with the pneumococcal conjugate vaccine has decreased in nasal carriage rates and pneumococcal disease in all age groups. Antibodies to capsular polysaccharide antigens provide serotype-specific protection against serious infections such as pneumonia, and the pneumococcal vaccines are designed to cover the serotypes most commonly associated with severe pneumococcal disease. Currently, a pneumococcal polysaccharide vaccine has a total of 23 serotypes that are 23 -valent and a 7 -valent polysaccharideprotein conjugate vaccine has been marketed internationally. Both vaccines are considered very safe. Respiratory secretions from the patient and direct contact with the healthy person pneumococci are getting transmitted. There are serious pneumococcal infections such as pneumonia, meningitis, and febrile bacteremia, and other respiratory disorders that are more common but have less serious manifestations.

The previous study demonstrated that pneumonia is a leading cause of community-acquired pneumonia irrespective of comorbidity, individuals with chronic lung diseases, particu-

\section{Corresponding Author:}

Dr. M. P. Brundha, Department of Pathology, Saveetha Dental College, Saveetha Institute of Medical and Technical Science, Saveetha University, 162 Poonamallee High Road, Chennai - 600077, Tamil Nadu, India; Phone: 9884421482; Email: brundha.sdc@saveetha.com

ISSN: $2231-2196$ (Print)

Received: 18.08 .2020
ISSN: 0975-5241 (Online)

Revised: 15.09.2020
Accepted: 18.10 .2020 
larly those with COPD, are at increased risk of pneumococcal community-acquired pneumonia and invasive pneumococcal disease, are prone to higher rates of complications and mortality and suffer prolonged recovery after such illnesses ${ }^{4}$. One study shows acute pulmonary embolism and Chest CT plays an important role in the management of patients with COVID $19^{5}$. The symptoms of coronavirus are similar to influenza that is fever, cough, sore throat, and also major respiratory problems that are a problem in breathing and highly prevalent shown in one study ${ }^{6}$. COVID 19 does not cause Nocturia ${ }^{7}$. Diabetic people can be a risk factor of COVID $19^{8}$. Generally, coronaviruses were not considered to be highly pathogenic to humans until the outbreak of Severe Acute Respiratory Syndrome (SARS) in 2002 and $2003^{9}$. Hysterectomy can be risky during COVID $19^{10}$. It alters the hemoglobin level ${ }^{11}$. Lung cancer patients have higher chances of SARS ${ }^{12}$. To understand how vaccination can stop a disease spreading through an otherwise susceptible population it can be done by game-based learning methods ${ }^{13}$. Vitamins help in fighting COVID $19^{14}$. This review of the literature has been done by collecting and retrieving information for a minimum of 30 articles. Articles were selected from Pubmed, google scholar, etc.

\section{COVID-19 AND ANTI-PNEUMOCOCCAL ANTIBODY}

\section{CoVID-19 Pneumonia}

COVID-19 pneumonia is a specific disease with hypoxemia and is also associated with normal respiratory compliance ${ }^{15}$. Hypoxemic patients have the same single etiology (SARSCoV-2 ) but show different symptoms from others like normal breathing ("silent" hypoxemia) or remarkably dyspneic; quite responsive to nitric oxide or not.

A previous study demonstrated the beginning of COVID 19 Pneumonia having characteristics of Low elastance which estimates that the amount of gas in the lung is nearly normal ${ }^{16}$. Low ventilation -to-perfusion, low lung weight, and low lung recruit ability, the amount of non-aerated tissue are very low; consequently, the recruiting ability is low ${ }^{17}$ these are L-type COVID-19 Pneumonia. H-type COVID-19 Pneumonia has characteristics of High elastance that is the decrease in gas volume due to increased edema accounts for the increased lung elastance, High right-to-left shunt. Due to increased edema and superimposed pressure in the dependent lung regions, it will be developed by the fraction of cardiac output perfusing the non-aerated tissue. High lung weight that is quantitative analysis of the $\mathrm{CT}$ scan shows a remarkable increase in lung weight $(>1.5 \mathrm{~kg})$, on the order of magnitude of severe ARDS ${ }^{18}$. High lung recruit ability that is an increased amount of non-aerated tissue is associated, as in severe ARDS, with increased recruit ability.
The Type H pattern, $20-30 \%$ of patients in our series, fully fit the severe ARDS criteria: hypoxemia, bilateral infiltrates, decreased respiratory system compliance, increased lung weight, and potential for recruitment. Type $\mathrm{L}$ and Type $\mathrm{H}$ patients are best identified by CT scan and are affected by different pathophysiological mechanisms ${ }^{19}$. COVID 19 can alter hemoglobin level ${ }^{20}$. Ankylosing spondylitis patients on biologics should take extra precautions to minimize the risk of contracting a COVID-19 infection ${ }^{21}$. Cancer people should be more careful ${ }^{22}$.

\section{Anti- Pneumococcal Antibody}

Streptococcus pneumonia is an important human pathogen causing asymptomatic carriage as well as important mucosal and systemic infections. Anti-capsular antibodies are thought to represent the single most important protective mechanism against invasive disease ${ }^{23}$. Antibodies to pneumococcal capsular polysaccharides were the basis of serum therapy in which passively transferred, serotype-specific anti-pneumococcal serum was shown to reduce mortality from pneumococcal pneumonia by half. Resistance to pneumococcal colonization is determined by the antibodies to the pathogen. Anti capsular antibodies reduce the pneumococcal colonization and protect nasopharyngeal carriage ${ }^{24}$. The WHO has anticipated new modifications in antibody assays for pneumococcal anti-capsular antibodies which can be useful for the people. There is an outlined principle to determine to change the protective concentration of such assay modification. For improvement of ELISA for anti-capsular antibodies this principle was applied, i.e. absorption with $22 \mathrm{~F}$ pneumococcal polysaccharide, that increases the specificity of the assay for vaccine serotype anti-capsular antibodies by removing non-specific antibodies ${ }^{25}$. Liquid Paraffin on Antibody Responses and Local Adverse Reactions of Bivalent Oil Adjuvanted Vaccines Containing Newcastle Disease Virus and Infectious Bronchitis Virus ${ }^{26}$.

\section{Detection of Specific Antibodies to SARS}

One study reported the evaluation of recombinant severe acute respiratory syndrome (SARS) coronavirus (SARS$\mathrm{CoV}$ ) nucleocapsid protein enzyme-linked immunosorbent assay (ELISA)-based antibody tests for serodiagnosis of SARS-CoV pneumonia and compare the sensitivities and specificities of this ELISA for detection of immunoglobulin $\mathrm{G}(\operatorname{IgG}), \operatorname{IgM}, \operatorname{Ig} A$, and their combinations with serum samples from healthy blood donors ${ }^{27}$. The specificities of the ELISA for IgG, IgM, and IgA detection were higher respectively. The test for diagnosis of SARS-CoV pneumonia is sensitive which is done by ELISA and does not require the cultivation of SARS-CoV ${ }^{28}$. Isolation of coronavirus is insensitive in clinical laboratories for diagnosis of SARS-CoV, while the detection of viral RNA by reverse transcriptionPCR can achieve a sensitivity of only 50 to $79 \%$, depending 
on the type and number of clinical specimens collected and the protocol used ${ }^{29,30}$. During the SARS epidemic, using the ELISA test will be useful for the diagnosis of SARS-CoV pneumonia. It is well known that in the presence of possible cross-reactions, the positive predictive value of serological tests depends on the prevalence of the infection in a particular location at a particular moment. On the other hand, the positive predictive value of the serological test would be increased if the prevalence of the infection is high, such as during an epidemic and when applied in clinically compatible cases ${ }^{31}$.

\section{Vaccine Development}

One study reported that the Polysaccharides that were identified coursing along the exterior of the bacterium could be targeted for vaccine development. British physician Sir Almroth Wright conducted the first large clinical trial of a wholecell pneumococcal vaccine.

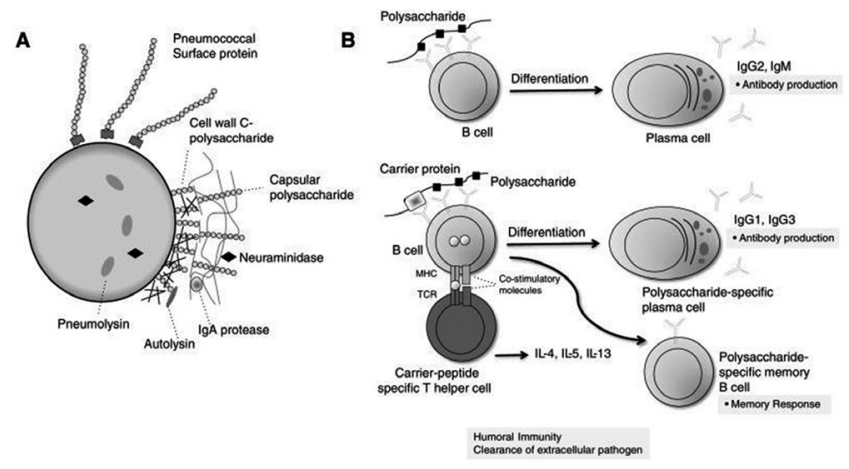

Figure 1: (A): Pneumococcus bacteria and virulence factors including capsular polysaccharide, $(B)$ : Immune response to polysaccharide and protein-polysaccharide conjugate vaccines. ${ }^{32}$

For the next three decades, the trial for vaccine development was largely unsuccessful. Streptococcus pneumonia is a bacterium with 93 different polysaccharide capsular serotypes as shown in Figure 1A, the most important determinant of pneumococcal virulence is an antiphagocytic bacterial capsule. Immune response to polysaccharide and protein-polysaccharide conjugate vaccines in Figure 1B.

Polysaccharide pneumococcal vaccines have evolved over the past 20 years, using both unconjugated polysaccharides and polysaccharides conjugated to toxins to elicit a protective immune response in groups at risk for pneumococcal infection. Current CDC immunization guidelines for these vaccines have reduced the rates of pneumococcal infections within immunized communities ${ }^{33}$. Vaccines against pneumonia, such as a pneumococcal vaccine, do protect against the COVID 19. The virus is new so it will take some time for the production of the vaccine against it. A pneumococcal vaccine is not enough for this virus. Scientists are trying to develop a vaccine against coronavirus as the pneumococcal vaccine is not enough.

One study reported that stem cells are unspecialized cells that have a property of differentiating into specific specialized cell types ${ }^{34}$. Using umbilical cord mesenchymal stem cells, protection against coronavirus can be done in the future. As vaccination is important for everyone ${ }^{35}$.

\section{Table 1: Advantages and disadvantages of 23-valent PS vaccine}

Pros Cons

- The vaccine covers a - Cannot be used on chillarge number of serotypes

- Serotypes covered account for $85-90 \%$ of invasive pneumococcal diseases in the US (ACIP, 1997)

- It is cost effective and widely used in developing countries dren $<2$ years

- Cannot be used on immunodeficient patients

- Time period of protection is limited because of no T-cell response (Bogaert, 2004).

- Does not affect carrier rate due to no mucosal immunity (Pletz et al. 2008)

Table 2: Advantages and disadvantages of PCV-7 conjugate vaccine ${ }^{36}$

Pros Cons

- More immunogenic than 23- valent PS vaccine

- Can be used on infants under 2 years of age

- Provides both, systemic and mucosal immunity

- Limit to the amount of polysaccharide-protein linkages that can be formed

- Not cost effective

\section{CONCLUSION}

COVID-19 pneumonia is a specific disease with hypoxemia and is also associated with normal respiratory compliance. Hypoxemic patients have the same single etiology (SARSCoV-2) but show different symptoms from others like normal breathing ("silent" hypoxemia) or remarkably dyspneic; quite responsive to nitric oxide or not. Polysaccharide pneumococcal vaccines have evolved over the past 20 years, using both unconjugated polysaccharides and polysaccharides conjugated to toxins to elicit a protective immune response in groups at risk for pneumococcal infection. Current CDC immunization guidelines for these vaccines have reduced the rates of pneumococcal infections within immunized communities. Vaccines against pneumonia, such as a pneumococcal vaccine, do protect against the COVID 19. The coronavirus infection has recently arisen as a pandemic and found to affect the organ systems especially, the lungs severely. So, the 
researchers started the production of the vaccine against it to prevent the infection. The vaccination which is currently used to protect older people from pneumonia targets a type of bacteria called Streptococcus pneumonia is suspected to be useful for coronavirus infection also but has no clinical evidence ${ }^{37}$. This review thus highlights the urge for further experimental validation on the cross-protection of the same for COVID disease.

\section{ACKNOWLEDGMENT}

Authors acknowledge the immense help received from the scholars whose articles are cited and included in references to this manuscript. The authors are also grateful to authors / editors / publishers of all those articles, journals, and books from which the literature for this article has been reviewed and discussed.

\section{Conflict of Interest: Nil}

\section{Source of Funding: Nil}

\section{REFERENCES}

1. Go E, Ballas Z. Anti-pneumococcal antibody response in normal subjects: A meta-analysis [Internet]. Vol. 98, Journal of Allergy and Clinical Immunology. 1996. p. 205-15. Available from: http://dx.doi.org/10.1016/s0091-6749(96)70244-0

2. Book Review Pneumonia and Serum Therapy. Frederick T. Lord and Roderick Heffron. 148 pp. New York: The Commonwealth Fund, 1938. \$1.00 [Internet]. Vol. 219, New England Journal of Medicine. 1938. p. 816-816. Available from: http://dx.doi. org/10.1056/nejm193811172192025

3. Daly TM, Hill HR. Use and Clinical Interpretation of Pneumococcal Antibody Measurements in the Evaluation of Humoral Immune Function [Internet]. Vol. 22, Clinical and Vaccine Immunology. 2015. p. 148-52. Available from: http://dx.doi. org/10.1128/cvi.00735-14

4. Torres A, Blasi F, Dartois N, Akova M. Which individuals are at increased risk of pneumococcal disease and why? Impact of COPD, asthma, smoking, diabetes, and/or chronic heart disease on community-acquired pneumonia and invasive pneumococcal disease. Thorax. 2015 Oct; 70(10):984-9.

5. Grillet F, Behr J, Calame P, Aubry S, Delabrousse E. Acute Pulmonary Embolism Associated with COVID-19 Pneumonia Detected by Pulmonary CT Angiography [Internet]. Radiology. 2020. p. 201544. Available from: http://dx.doi.org/10.1148/radiol.2020201544

6. Zhao D, Yao F, Wang L, Zheng L, Gao Y, Ye J, et al. A comparative study on the clinical features of COVID-19 pneumonia to other pneumonia. Clin Infect Dis [Internet]. 2020 Mar 12; Available from http://dx.doi.org/10.1093/cid/ciaa247

7. Kumar MDA, Ashok Kumar MD, Brundha MP. Awareness about nocturia-A questionnaire survey [Internet]. Vol. 9, Research Journal of Pharmacy and Technology. 2016. p. 1707. Available from: http://dx.doi.org/10.5958/0974-360x.2016.00344.9

8. Preetika S, Brundha MP. Awareness of diabetes mellitus among the general population [Internet]. Vol. 11, Research Journal of Pharmacy and Technology. 2018. p. 1825. Available from: http:// dx.doi.org/10.5958/0974-360x.2018.00339.6
9. Cui J, Li F, Shi Z-L. Origin and evolution of pathogenic coronaviruses [Internet]. Vol. 17, Nature Reviews Microbiology. 2019. p. 181-92. Available from: http://dx.doi.org/10.1038/s41579018-0118-9

10. Kalaiselvi R, Brundha MP. Prevalence of hysterectomy in the South Indian population [Internet]. Vol. 9, Research Journal of Pharmacy and Technology. 2016. p. 1941. Available from: http:// dx.doi.org/10.5958/0974-360x.2016.00398.x

11. Brundha MP, Padma Shri VP, Sundari S. Quantitative Changes of Red Blood cells in Cancer Patients under Palliative Radiotherapy-A Retrospective Study [Internet]. Vol. 12, Research Journal of Pharmacy and Technology. 2019. p. 687. Available from: http://dx.doi.org/10.5958/0974-360x.2019.00122.7

12. Bokadia GS, Sneha. Bokadia G, Brundha MP, Ariga P. Current knowledge about lung cancer among middle-aged nonmedical males a questionnaire-based survey [Internet]. Vol. 11, Research Journal of Pharmacy and Technology. 2018. p. 2565. Available from: http://dx.doi.org/10.5958/0974-360x.2018.00474.2

13. Mp B, Brundha MP, Nallaswamy D. Hide and seek in pathology- A research on game-based histopathology learning [Internet]. Vol. 10, International Journal of Research in Pharmaceutical Sciences. 2019. p. 1410-4. Available from: http://dx.doi. org/10.26452/ijrps.v10i2.606

14. John DA, Brundha MP. Awareness of Vitamin A Deficiency among Middle-Aged Men-Research [Internet]. Vol. 05, Vitamins \& Minerals. 2016. Available from: http://dx.doi. org/10.4172/2376-1318.1000144

15. Wang X, Guo W, Hu Y, Wu J, Wei H. Nanozymes: Next Wave of Artificial Enzymes. Springer; 2016. 127 p.

16. Gattinoni L, Pesenti A, Avalli L, Rossi F, Bombino M. PressureVolume Curve of Total Respiratory System in Acute Respiratory Failure: Computed Tomographic Scan Study [Internet]. Vol. 136, American Review of Respiratory Disease. 1987. p. 730-6. Available from: http://dx.doi.org/10.1164/ajrccm/136.3.730

17. Gattinoni L, Caironi P, Cressoni M, Chiumello D, Marco Ranieri V, Quintel M, et al. Lung Recruitment in Patients with Acute Respiratory Distress Syndrome [Internet]. Vol. 354, New England Journal of Medicine. 2006. p. 1775-86. Available from: http://dx.doi.org/10.1056/nejmoa052052

18. Maiolo G, Collino F, Vazquez F, Rapetti F, Tonetti T, Romitti F, et al. Reclassifying Acute Respiratory Distress Syndrome [Internet]. Vol. 197, American Journal of Respiratory and Critical Care Medicine. 2018. p. 1586-95. Available from: http://dx.doi. org/10.1164/rccm.201709-1804oc

19. Gattinoni L, Chiumello D, Caironi P, Busana M, Romitti F, Brazzi L, et al. COVID-19 pneumonia: different respiratory treatments for different phenotypes? Intensive Care Med [Internet]. 2020 Apr 14; Available from http://dx.doi.org/10.1007/ s00134-020-06033-2

20. Shreya S, Brundha MP. Alteration of Haemoglobin Value about Age, Sex, and Dental Diseases-A Retrospective Correlation Study [Internet]. Vol. 10, Research Journal of Pharmacy and Technology. 2017. p. 1363. Available from: http://dx.doi. org/10.5958/0974-360x.2017.00241.4

21. Brundha MP, Visha MG. A review on ankylosing spondylitis [Internet]. Vol. 3, International Journal of Clinicopathological Correlation. 2019. p. 44. Available from: http://dx.doi.org/10.4103/ ijcpc.ijcpc_12_19

22. Brundha MP, Sai Vignesh S. Myeloid sarcoma [Internet]. Vol. 3, International Journal of Clinicopathological Correlation. 2019. p. 41. Available from: http://dx.doi.org/10.4103/ijcpc. ijcpc_11_19

23. Cook G. Immunobiology: The Immune System in Health and Disease (4th in) by C.A. Janeway, P. Travers, M. Walport, 
and J.D. Capra [Internet]. Vol. 21, Immunology Today. 2000. p. 201. Available from: http://dx.doi.org/10.1016/s01675699(00)01613-3

24. Balaji S, Brundha. MP, Path DNB. Awareness of Breast Cancer among Dental Surgeons.

25. Siber GR, Chang I, Baker S, Feinstein P, O'Brien KL, Santosham $\mathrm{M}$, et al. Estimating the protective concentration of anti-pneumococcal capsular polysaccharide antibodies [Internet]. Vol. 25, Vaccine. 2007. p. 3816-26. Available from: http:// dx.doi.org/10.1016/j.vaccine.2007.01.119

26. Hannah R, Ramani P, Brundha MP, Herald. J. Sherlin, Ranjith G, Ramasubramanian A, et al. Liquid Paraffin as a Rehydrant for Air Dried Buccal Smear [Internet]. Vol. 12, Research Journal of Pharmacy and Technology. 2019. p. 1197. Available from: http:// dx.doi.org/10.5958/0974-360x.2019.00199.9

27. Shenoy PB, Brundha MP. Awareness of polycystic ovarian disease among females of age group 18-30 years. J Pharm Sci [Internet]. 2016; Available from http://search.proquest. com/openview/a8a09e7b2e9d2f967bf3fee479c7018a/1?pqorigsite $=$ gscholar \&cbl $=54977$

28. Woo PCY, Lau SKP, Wong BHL, Tsoi H-W, Fung AMY, Chan $\mathrm{K}-\mathrm{H}$, et al. Detection of specific antibodies to severe acute respiratory syndrome (SARS) coronavirus nucleocapsid protein for serodiagnosis of SARS coronavirus pneumonia. J Clin Microbiol. 2004 May;42(5):2306-9.

29. Yam WC, Chan KH, Poon LLM, Guan Y, Yuen KY, Seto WH, et al. Evaluation of Reverse Transcription-PCR Assays for Rapid Diagnosis of Severe Acute Respiratory Syndrome Associated with a Novel Coronavirus [Internet]. Vol. 41, Journal of Clinical Microbiology. 2003. p. 4521-4. Available from: http://dx.doi. org $/ 10.1128 / \mathrm{jcm} .41 .10 .4521-4524.2003$

30. Ferdioz J, Brundha MP. Awareness of stye. International Journal of Pharmaceutical Sciences Review and Research. 2016 Jan $1 ; 40(1): 30-2$.
31. Ravichandran H, Brundha MP. Awareness about personal protective equipments in hospital workers (sweepers and cleaners). International Journal of Pharmaceutical Sciences Review and Research. 2016;40(1):28-9.

32. Pollard AJ, Perrett KP, Beverley PC. Maintaining protection against invasive bacteria with protein-polysaccharide conjugate vaccines. Nat Rev Immunol. 2009 Mar;9(3):213-20.

33. Brundha MP. A Comparative Study- The Role of Skin and Nerve Biopsy in Hansen's Disease.

34. Timothy CN, Samyuktha PS, Brundha MP. Dental pulp Stem Cells in Regenerative Medicine - A Literature Review [Internet]. Vol. 12, Research Journal of Pharmacy and Technology. 2019. p. 4052. Available from: http://dx.doi.org/10.5958/0974360x.2019.00698.x

35. Harsha L, Brundha MP. Prevalence of dental developmental anomalies among men and women and its psychological effect in a given population. J Pharm Sci [Internet]. 2017; Available from http://search.proquest.com/openview/1f488cc6e377096f4 4a87e509aceab79/1?pq-origsite $=$ gscholar $\& \mathrm{cbl}=54977$

36. Hernández-García I, Aibar-Remón C. Effectiveness of an intervention to improve the vaccination coverage against Streptococcus pneumoniae in patients with chronic kidney disease [Internet]. Human Vaccines \& Immunotherapeutics. 2020. p. 1-3. Available from: http://dx.doi.org/10.1080/21645515.2020. 1759975

37. Prashanthi N, Brundha MP. A Comparative Study between Popplet Notes and Conventional Notes for Learning Pathology [Internet]. Vol. 11, Research Journal of Pharmacy and Technology. 2018. p. 175. Available from: http://dx.doi.org/10.5958/0974360x.2018.00032.x 